\title{
Genetic and Environmental Factors Contributing to Reproductive Success and Failure in Potato
}

\author{
Paul C. Bethke ${ }^{1}$. Shelley H. Jansky ${ }^{1}$ \\ Accepted: 18 November 2020 / Published online: 6 January 2021 \\ (C) The Author(s) 2021, corrected publication 2021
}

\begin{abstract}
The foundation of potato (Solanum tuberosum) breeding and the development of new potato varieties is the crossing of parents to produce seeds that contain new combinations of alleles that may be superior to those in either parent. In this review, we begin by highlighting a signature problem of potato breeding, the widespread lack of fertility observed in many lines. We summarize normal development of male and female reproductive structures, fertilization and embryo growth. Various manifestations of male and female sterility are then described. These include defects of meiosis and mitosis, bud abscission, competition between reproductive structures and tubers for resources, and cytoplasmic male sterility. Effects of environmental determinants, such as temperature and light intensity, on fertility are discussed. Finally, suggested best practices that promote fertility are provided as a guide for those conducting breeding and genetics work with potato.
\end{abstract}

\section{Resumen}

Los cimientos del mejoramiento de la papa (Solanum tuberosum) y el desarrollo de nuevas variedades es el cruzamiento de los padres para producir semillas que contengan nuevas combinaciones de alelos que pudieran ser superiores a las de cualquiera de los progenitores. En esta revisión, empezamos por resaltar un problema característico del mejoramiento de la papa, la ampliamente dispersa falta de fertilidad observada en muchas líneas. Resumimos el desarrollo normal de las estructuras reproductivas de macho y hembra, fertilización y crecimiento del embrión. Después se describen varias manifestaciones de esterilidad de hembra y macho. Esto incluye defectos en la meiosis y mitosis, abscisión de la yema, competencia entre estructuras reproductivas y tubérculos por recursos, y la esterilidad citoplásmica masculina. Se discuten los efectos de los determinantes ambientales, tales como la temperatura y la intensidad de luz en la fertilidad. Finalmente, se proporcionan sugerencias de las mejores prácticas que promuevan la fertilidad como guía para aquellos que desarrollan actividades de mejoramiento y genética con papa.

Keywords Pollen sterility $\cdot$ Floral bud abortion $\cdot$ High temperature stress $\cdot$ Sensitive cytoplasm $\cdot$ Potato breeding methods $\cdot$ Potato germplasm

\section{Introduction}

"The greatest difficulty encountered in the breeding of the potato from seed is the marked sterility or lack of fruitfulness very generally present. This has been experienced

Paul C. Bethke

Paul.bethke@usda.gov

1 Vegetable Crops Research Unit USDA-ARS and Department of Horticulture, University of Wisconsin, USDA-ARS, 1575 Linden Drive, Madison, WI 53706, USA by all who have sought to breed this plant." (Stout and Clark 1924).

The foundation of potato (Solanum tuberosum) breeding and the development of new potato varieties is the crossing of parents to produce seeds that contain new combinations of alleles that may be superior to those in either parent. Consequently, some amount of sexual reproduction is necessary for potato improvement. Since the commercial crop is asexually propagated, however, few research efforts have focused on optimizing seed production in potato. The potato breeding community is currently exploring the possibility of producing diploid hybrid potato varieties (Lindhout et al. 2011; Jansky et al. 2016). If this strategy proves to be feasible, 
then it will be important to produce high quality true potato seed in large quantity. Improvements in sexual reproduction will be a critical step toward achieving this goal.

At the beginning of the twentieth century, demand for potatoes was exceeding production in the United States (East 1908 b). As noted by the eminent potato grower Eugene Grubb (1912), the 1911 crop was many million bushels short of demand. East (1908b) suggested that plant breeders should try to supply the market by developing better varieties. Potato breeders working in the second half of the previous century had developed highly successful varieties by selecting seedlings produced from open pollinated berries (Goodrich 1863; Sutton 1898; Glendinning 1983), but this process had been largely abandoned in the U. S. by the early twentieth century (Clark et al. 1931; Krantz et al. 1939). Instead, North American potato breeders were focused on clonal selection for variety improvement (Krantz 1924), although a few individuals continued work with hybridization (East 1908b; Fitch 1910; Stuart 1914). The establishment of a USDA potato breeding program in 1910 and a National Potato Breeding Program in 1929 stimulated renewed interest in true seed production as a method to create new genetic combinations for selection efforts. At that time, most potato breeders relied on berries produced in the field. The process was, at best, inefficient and frustrating for breeders working in cool climates and nearly futile for breeders working in the South (Stevenson and Clark 1937). It is not surprising, then, that many studies in the early 1900's examined the genetic and environmental determinants of flowering, berry formation, and seed production. Those studies were carried out to establish effective protocols for making potato seeds that would be used for variety development. In this review, we revisit this early work, as well as more contemporary research, to provide a synthesis of research on fertility and true potato seed production. Findings from this research, some of it a century old, are relevant today for potato breeders and for those developing potato varieties that can be propagated from true potato seed.

\section{The Problem}

"The crossing of potato is not always an easy problem. Many of our commercial varieties fail to bloom, or the blossoms fail to set fruit. Potato anthers have very little pollen, and in many cases this is sterile, or the percentage of viable pollen is so small as to reduce the chances of a successful pollination and fertilization to a minimum." (Newman and Leonian 1918).

A general lack of potato fertility was observed frequently by researchers early in the twentieth century. East (1908a) wrote that many varieties never or at most rarely set seed. Fitch (1910) and Hardenburg (1933) observed that a lack of viable pollen interfered with crossing. Krantz (1924) and
Stout and Clark (1924), perhaps stating the obvious, noted that the inability of cultivars to produce berries was a significant hindrance to sexual breeding work. The situation did not improve with time. Arnason (1941) would continue the refrain, stating that "Each of the commercial varieties of potatoes has its own combination of characters, good and bad. The incorporation of the good characters of different clones in individual derivatives is difficult because of the sterility of most of the commercial varieties." The situation was especially acute outside of the Northern states. Stevenson and Akeley (1947) related that many people living in the South, or where the climate is hot and dry, had never seen a seedball growing on a potato plant.

The widespread lack of fertility observed in the early twentieth century was remarkable given that practically every variety raised in Europe and North America since 1588 had originated from true seed (Salaman 1926). How did abysmally low fertility arise so quickly in potato? Hardenburg (1933) provided a straightforward explanation. "Seedballs are not nearly so commonly found in our potato fields today as they were forty years ago. The reason is that we are not growing the same varieties now as then."

\section{Normal Reproductive Development}

"The well-known flower of the potato plant is a hermaphrodite, that is to say, both male and female elements are contained in one and the same flower." (Salaman 1920).

Potatoes have perfect flowers, with each flower producing stamens and pistils. Clones of temperate zone potato will generally bloom 60 days after planting in the field (Edmundson 1941; Plaisted 1980). Photographs showing the parts of a potato flower can be found in (Ordoñez et al. 2017). An overview of floral development is provided by Schark (1957). Microsporogenesis precedes megasporogenesis (Clarke 1940), and mature male gametophytes (pollen grains) are typically formed before the female gametophytes (embryo sacs) have completed their mitotic divisions. Clarke (1940) observed that reduction divisions in the anther precede those in the ovule, as tetrads of microspores were observed in flowers in which the megaspore mother cells of the ovules had not yet begun to divide. In one study on S. tuberosum subsp. phureja, no ovules were mature prior to anthesis (Olson 1987). On the day of anthesis, $13 \%$ of ovules were mature; 1, 2 and 3 days after anthesis, $38 \%, 75 \%$, and over $80 \%$ of ovules, respectively, were mature. This gradual maturation of ovules prolongs the period that flowers are receptive to fertilization, enhancing the chance for successful seed production. If flowers are not pollinated, the floral tissues deteriorate, and flowers abscise approximately 4 days after opening (East 1908a). 


\section{Formation of Gametes}

Developing pollen grains are nourished by the tapetum, which lies adjacent to sporogenous tissue in the anther. Microsporogenesis in the sporogenous tissue begins with differentiation of microsporocytes (pollen mother cells). These produce tetrads of microspores that separate into individual spores after meiosis. Cytoplasmic connections among pollen mother cells result in synchronous meiotic divisions within the locule of an anther (Mascarenhas 1975). Meiotic divisions may or may not be synchronous with other anthers in the same bud (Schark 1957). Callose walls form around each microspore soon after meiosis is completed. Individual microspores undergo mitosis to produce a microgametophyte with a generative cell inside a tube cell. The generative cell undergoes mitosis again to produce two male gametes (sperm cells). Plastids may be present in the generative cell, but they are degraded before the second mitotic division (Greiner et al. 2015). In tetraploid potato, the mature microgametophyte (pollen grain) is about $35 \mu \mathrm{m}$ in diameter (East 1908b; Fineman 1947).

There are several hundred ovules in an ovary and each ovule contains a megaspore mother cell. This cell undergoes meiosis to produce four megaspores, three of which degenerate. The remaining megaspore undergoes three mitotic divisions to produce the megagametophyte (embryo sac) with seven cells containing eight nuclei. The megagametophyte is composed of three antipodal cells that may degenerate early or persist until after fertilization and, at the opposite pole, two synergids flanking a female gamete (egg cell); the central cell in the middle of the megagametophyte contains two polar nuclei that fuse before fertilization (Clarke 1940). Developmental stages from embryo sac formation to early embryo growth are illustrated in Clarke (1940).

\section{Dehiscence and Spread of Pollen}

Pollen in the two- or three-celled stage leaves the anther through a pore that forms at the apical end (Dnyansagar and Cooper 1960). Robbins (1917) found that pollen is usually shed on the second day of blooming, at which time the pistil is most receptive. The duration of pollen production is about two days (Janssen and Hermsen 1976).

Outdoors, bumblebees (Bombus spp.) pollinate potato plants. Glendinning (1976) described the fascinating behavior of bumblebees this way. "A bumble-bee alights on the anthercone and its weight causes the flower to hang down. It then vibrates the anthers, and pollen falls onto its abdomen and also onto the stigma. If it obtains much pollen it hangs from the flower while collecting it to its pollen baskets; occasionally, when pollen is abundant, it may renew its grip on the anther and repeat the process. Visits to less productive flowers are briefer and do not involve collection of pollen to the pollen baskets." Bumblebees are remarkably selective, preferentially visiting plants with abundant, healthy pollen and avoiding those that produce little or shriveled pollen (Sanford and Hanneman 1981; Arndt and Peloquin 1990; Batra 1993). The means that bees use to determine the quality of pollen grains from a distance is unknown. Bee pollination results in self-fertilization much more commonly than cross-fertilization (Plaisted 1980). In one study, the ratio of self- to crosspollination was found to be four to one (Glendinning 1976).

\section{Fertilization and Maturation of the Seeds and Fruit}

Viable pollen grains that land on the stigma of a receptive flower may germinate in as little as $30 \mathrm{~min}$ (Bradshaw and MacKay 1994). A pollen tube grows through a pore in the pollen wall and then penetrates the stigma and elongates through the style. Photographs showing pollen tube growth through the style are included in Ordoñez et al. (2017). The vegetative nucleus enters the pollen tube first, followed by the male gametes (Dnyansagar and Cooper 1960). Pollen grains on the stigma may germinate over an extended period of time, presumably in response to chemical signals exchanged between the stigma and the pollen. In one study, some germinated pollen grains were observed $24 \mathrm{~h}$ after pollination. Others remained quiescent for a time and germinated between 24 and $72 \mathrm{~h}$ after landing on the stigma (Plaisted 1980). Because of the large number of ovules in each ovary, and because the ovules mature at different rates, fertilization of all functional eggs occurs rarely, even after heavy pollination (Arnason 1943).

Fertilization occurs when sperm nuclei from the pollen tube enter the ovule through an opening called the micropyle. In Irish Cobbler, pollen tubes were part way down the style one day after pollination and only a few pollen tubes had reached the embryo sac two days after pollination (Arnason 1943). Arnason suggested that in this variety, most ovules were fertilized 2-4 days after pollination. As described in Plaisted (1980), Hoopes (1977) found that pollen tubes of Tuberosum $x$ Andigena hybrids grew the length of the style within $20 \mathrm{~h}$. The pollen tube penetrates the female gametophyte between a synergid and the egg cell, allowing one sperm to fertilize the egg cell and the other sperm to fertilize the central cell. As outlined in Table 1, the endosperm begins to divide before the zygote does and fertilization occurs $24-72 \mathrm{~h}$ after pollination.

Early embryo development in S. tuberosum subsp. phureja was described and illustrated in detail by Dnyansagar and Cooper (1960). The mature ovule is approximately $150 \mu \mathrm{m}$ in length. Within the ovule, the nutritive endothelium surrounds the megagametophyte and lies adjacent to the 
Table 1 Timing of events after pollination that lead to the production of potato seeds in diploid $(2 \mathrm{x})$ and tetraploid $(4 \mathrm{x})$ potatoes $(\mathrm{h}=$ hours, $\mathrm{d}=$ days)

\begin{tabular}{llll}
\hline Event & $4 \mathrm{x}^{\mathrm{a}}$ & $4 \mathrm{x}^{\mathrm{b}}$ & $2 \mathrm{x}^{\mathrm{c}}$ \\
\hline Double fertilization & $40-45 \mathrm{~h}$ & $36 \mathrm{~h}$ & $24-72 \mathrm{~h}$ \\
First division of endosperm & $60-70 \mathrm{~h}$ & $46-58 \mathrm{~h}$ & $72-96 \mathrm{~h}$ \\
First division of the zygote & $5 \mathrm{~d}$ & $4-5 \mathrm{~d}$ & $4-6 \mathrm{~d}$ \\
Seed coat thickens & $12 \mathrm{~d}$ & & $14-16 \mathrm{~d}$ \\
Maximum endosperm development & & & $14 \mathrm{~d}$ \\
Epicotyl, hypocotyl, cotyledons formed & $16 \mathrm{~d}$ & $15-19 \mathrm{~d}$ \\
\hline
\end{tabular}

${ }^{a}$ Williams, 1954

${ }^{\mathrm{b}}$ Clarke, 1940

${ }^{\mathrm{c}}$ Dnyansagar and Cooper, 1960

integument, which will become the seed coat. After double fertilization, the cellular endosperm develops and the endothelial cells shrink. A haustorium forms at the chalazal (antipodal) end of the ovule and this replaces the endothelium as the source of nutrition for the developing endosperm. As the embryo reaches the heart-shaped stage of development, it begins to digest the endosperm. Two weeks after pollination, the outer epidermis of the ovule becomes cutinized and cell walls thicken to form the seed coat. Viable embryos can be excised 14 days after pollination (Haynes 1954). Berries are generally mature by six weeks after pollination (Simmonds 1997). The minimum time for full development of viable seed has been suggested to be five (Jansky et al. 2012) or six weeks after pollination (Simmonds 1963).

\section{Reasons for Inadequate Berry and Seed Production}

"In all potato plants, however, when grown out in the open, successful fertilization, be it "selfing" or "crossing," is a hazardous undertaking, and I personally do not succeed in getting more than about $5 \%$ of the individual flowers I handle to set seed." (Salaman 1910).

The lack of fertility in early twentieth century potato varieties was readily apparent. "There are varieties which develop clusters of buds which fall without opening, and many more which produce flowers, all of which fall without setting fruit. Some of the anthers in the latter varieties contain no pollen, others shriveled pollen grains containing no protoplasm, while still others produce viable pollen though never (in my experience) in large quantities." (East 1908a). Multiple factors contribute to low fertility and sterility in potato. Ellison (1936) summarized research to date when he wrote that it is apparent that there are two main sources of sterility in the potato plant: genetic factors such as those that cause meiotic irregularities, and environmental influences affecting the development of floral parts. The genetic factors were, to a large extent, an unintended consequence of potato breeding efforts. Glendinning (1983) argued that widespread inbreeding of potato occurred following the late blight epidemics in the 1840's. One consequence of inbreeding was reduced fertility. He also noted that there had been selection for infertility on the part of potato breeders. Flowers and berries were thought to be undesirable because of a long-standing belief that flowering and fruiting depressed tuber yields (Knight 1812). Finally, attempts to broaden the genetic base of potato introduced a range of cytoplasmic sterility factors (Grun 1990). Details, such as they are known, about the genetic and environmental contributors to low fertility are reviewed below.

\section{Male Sterility}

"Another difficulty a potato raiser has is that a number of excellent varieties which produce beautiful blooms bear anthers which contain no pollen." (Salaman 1920).

Male sterility is common in potato cultivars (Salaman 1910; Stout and Clark 1924; Fukada 1925; Stow 1926; Ellison 1936; Krantz et al. 1939; Arnason 1941; Fineman 1947; Halsted 1890). "The whole race of cultivated potatoes is decidedly low in maleness." (Stout and Clark 1924). Pollen from 170 commercial varieties and 513 seedlings representing material from many parts of the world was examined by Stout and Clark (1924). All of the material had a fairly large percentage of sterile pollen grains. Sixty years later, another study of 676 genotypes found that $23 \%$ were completely male sterile (Gopal 1993). Types of male sterility include shriveled pollen, swollen pollen (high osmotic pressure due to disintegration of contents that has caused pollen grains to swell), anther degeneration and the absence of pollen (hypertrophied pollen mother cells fill the anther cavity) (Breeze 1921). It is interesting to note that even in highly fertile varieties, some pollen grains are inviable.

Stout and Clark (1924) placed 106 North American and European varieties and 27 South American landraces into four categories based on pollen development (Table 2). Scoring was carried out across two years in the cool field environment of Presque Isle, Maine, where conditions were favorable for pollen production. Two observations are immediately apparent. First, male fertility as assessed by pollen abundance, in vitro germination of pollen and success as a male parent, was low in most North American and European cultivars and second, male fertility was much higher in South American landraces than in North American and European cultivars. All of the North American and European cultivars were tetraploid. Many of the South American landraces were likely to be tetraploid $S$. tuberosum subsp. andigena, although some lines may have been diploid. As discussed below, normal 
Table 2 Categories of potato based on pollen features and percent of North American/European and South American genotypes in each category

\begin{tabular}{|c|c|c|c|c|c|}
\hline Anthers & Pollen & Germination & Male fertility & $\begin{array}{l}\text { North American/ } \\
\text { European }\end{array}$ & $\begin{array}{l}\text { South } \\
\text { American }\end{array}$ \\
\hline $\begin{array}{l}\text { Well-developed, orange, complete } \\
\text { dehiscence }\end{array}$ & $\begin{array}{l}\text { Abundant, }>30 \% \text { is plump } \\
\text { and contain granular material }\end{array}$ & $15-20 \%$ on sugar agar & Excellent male parent & $9 \%$ & $48 \%$ \\
\hline $\begin{array}{l}\text { Well-developed, orange, complete } \\
\text { dehiscence }\end{array}$ & $5-30 \%$ is plump & $\begin{array}{l}\text { Low, with feeble pollen } \\
\text { tube growth }\end{array}$ & Poor male parent & $12 \%$ & $30 \%$ \\
\hline $\begin{array}{l}\text { Well-developed, green at tips, some } \\
\text { anthers not dehiscent }\end{array}$ & $\begin{array}{l}\text { Abundant or scant, }<10 \% \text { is } \\
\text { plump }\end{array}$ & Rare & Rarely successful & $57 \%$ & $15 \%$ \\
\hline Greenish, irregular dehiscence & Scant, rarely plump & None & Not successful & $22 \%$ & $7 \%$ \\
\hline
\end{tabular}

Data from Stout and Clark 1924

meiosis is impeded by four sets of chromosomes, leading to fertility reductions in tetraploid potatoes. However, that is an unsatisfying explanation for the high levels of sterility in Northern Hemisphere cultivars compared to South American germplasm (Ames and Spooner 2008; Gutaker et al. 2019). It is more likely that cytoplasmic-genetic interactions are responsible for the low fertility in this germplasm.

The first stage at which male sterility may be expressed is in the development of sporogenous tissue on the anther wall. In Irish Cobbler buds collected from the field, the microsporogenous tissue often breaks down completely, leaving a mass of material in anther locules (Rees-Leonard 1935). Heterogeneity of pollen formation was apparent. All of the pollen was aborted in some locations within a locule, whereas pollen in other locations was mostly viable (Arnason 1941). In the sterile tetraploid B595-76, microsporogenesis proceeded normally until the pollen mother cells underwent meiosis (Schark 1957). Precursors to the microspore mother cells become plasmolyzed and, at later times, the cytoplasm of microspore mother cells appeared somewhat shrunken and the nuclei were abnormally granular (Schark 1957). Although the microspore mother cells completed meiosis, the resulting microspores collapsed and degenerated. This developmental failure may have resulted from an inability of the adjacent tapetum to provide an adequate supply of nutrients to the developing microspore mother cells. Schark (1957) hypothesized that increases in metabolic rates throughout the plant, such as those induced by high temperatures, might reduce the supply of nutrients to sporogenous tissue and lead to nutritional deficiencies.

Reduced male fertility may also reflect meiotic irregularities. Many meiotic abnormalities were noted by Ellison (1936) in a cytological study of 50 British cultivars. Meiotic irregularities in microsporogenesis included failure of chromosomes to pair, lagging chromosomes, and failure to complete the second division (Fineman 1947). Chromosomal imbalances due to unsuccessful chiasma formation have been reported in diploid cultivated potatoes (Carroll and Low 1976). However, dysfunctional meiotic timing mechanisms seem to cause microspore development problems more often than chromosomal imbalances. In some sterile varieties, meiosis began later than normal (Ellison 1936). This delay in the initiation of meiosis caused the spindle to collapse before the completion of meiosis I, leading to restitution nuclei (Ellison 1936). In other male sterile varieties, the first meiotic division is normal, but the second division is delayed, resulting in a failure of meiosis II (Arnason 1941). Chromosomes do not consistently separate into four groups of similar size, so dyads and triads form in addition to tetrads. In male sterile Russet Burbank (Netted Gem), microspore dyads were common in anthers, and buds appeared to abort before the second meiotic division was initiated (Arnason 1943).

\section{Female Sterility}

"The investigation of young ovules of several varieties of potatoes has revealed that in most of them a considerable proportion of ovules abort." (Arnason 1943).

Although male sterility is a greater concern for potato breeders than female sterility, statements such as these can be found: "The production of fruits containing viable seeds is the exception rather than the rule in the potato." (ReesLeonard 1935). Stout and Clark (1924) noted that only $14 \%$ of 588 genotypes grown in Maine produced open-pollinated berries even though pollen viability was good, suggesting that female fertility might be problematic. Using a stain-clearing technique to examine ovules microscopically, Stelly and Peloquin (1985) found that ovule sterility is common. The proportion of gametophytes aborted and degenerating ranged from less than $10 \%$ to more than $90 \%$.

Since potato varieties are tetraploid, low fertility may be due in part to difficulties encountered in meiosis, which would affect both female and male fertility. Meiotic abnormalities during megasporogenesis have been reported to be similar to those in microsporogenesis and include persistence of paired chromosomes and chromosome degeneration (Ellison 1936). Cultivars with meiotic irregularities on the male side also tend 
to have irregularities on the female side. In some varieties, however, meiotic failure is less conspicuous in ovules than in anthers. This may be explained in part by a mechanistic difference between microsporogenesis and megasporogenesis. On the male side, no cell plate forms after meiosis I. This provides an opportunity for meiotic failure if the products of meiosis I fuse and then do not separate at meiosis II. On the female side, because a plate forms after meiosis I, the risk of forming restitution nuclei is eliminated. Nevertheless, meiotic irregularities have been reported during megaspore development. In one variety with poor female fertility, one third of meiotic configurations were irregular and macrospore mother cells reached meiosis II later than normal in $40 \%$ of the ovules (Arnason 1943). Consequently, over $70 \%$ of ovules had unhealthy spores or embryo sacs. When megaspore and megagametophyte development fails or is delayed, the nutritive cells (endothelium) of the ovule enlarge. After double fertilization, the relative rates of endothelium and endosperm development determine whether an ovule will abort (Dnyansagar and Cooper 1960). In a normal ovule, the endosperm will be dominant, holding the endothelium in check. If the endosperm is not developing properly, then the endothelium digests adjacent tissues, including the endosperm, ultimately leading to embryo and seed abortion.

The proportion of functional macrospores is generally higher than that of functional microspores (Arnason 1943). Except for the most fertile varieties, there is no correspondence between male and female fertility, estimated from microscopic observations (Table 3). While varieties with high female fertility and low male fertility appear to be relatively common, the reverse is almost unheard of. Perhaps some genes responsible for ovule abortion also contribute to pollen sterility.

Even in female fertile varieties, the number of seeds produced is far fewer than the number of ovules in the ovary. In tetraploid potatoes, estimates of the number of ovules per ovary range from 600 to 900 (Arnason 1943) to 1000-1200 (Upadhya et al. 1985). Arnason (1943) estimated that there were 700 ovules per ovary in the tetraploid cultivar Earlaine. Since over $85 \%$ of ovules were viable in this variety, he calculated it might be expected to produce about 600 seeds per berry. Far fewer seeds were produced, however, even when abundant viable pollen was applied. Arnason concluded that because there are so many ovules in each ovary, fertilization of all functional egg cells probably occurs rarely, even after heavy pollination. This may be especially true if pollen is applied only once, as in Arnason (1943), because not all ovules mature at the same time. Upadhya et al. (1985) indicated that at most $30-40 \%$ of all ovules are fertilized, with the highest proportion of fertilized ovules at the stylar end of the fruit. In a study of one ovary five days after pollination, 18 ovules in the upper half had been fertilized, while 18 were unfertilized; in the lower half of the ovary, seven had been fertilized and 66 had not been fertilized (Arnason 1943).

Ovules mature across a period of time, presumably to maximize the possibility that pollen tubes will reach receptive ovules. On the day of petal opening, the percentage of ovules that are mature varies widely with genotype (Olson 1987; Stelly and Peloquin 1985). The stigma is receptive, with fully-developed turgid papillae, for 18-36 h (Upadhya et al. 1985). Because ovule maturation is asynchronous, three pollinations during this receptive period produces the highest berry set, the largest berries, and the greatest number of seeds per berry. Pollinating once versus three times produced 27.5\% vs $71 \%$ berry set and 35 vs. 217 seeds per berry (Pallais et al. 1984).

Because several hundred seeds may be produced even if over half of the ovules abort, female sterility is not as obvious as male sterility. Janssen and Hermsen (1976) predicted that above a certain level of pollen viability, differences in seed set resulting from differences in pollen viability are not detectable since there is a surplus of pollen on the stigma. They estimated the average number of pollen grains on a diploid stigma to be 1625 , while 2863 pollen grains adhered to tetraploid stigmas. Multiplying percent in vitro pollen germination by the number of pollen grains on a stigma provides a predicted number of seeds that should be produced (Table 4). With one exception, this calculation always overestimated the number of seeds produced in the diploid germplasm they used. The highest number of seeds was 143, even though 796 seeds were
Table 3 Estimated proportion of viable pollen and embryo sacs produced by potato varieties and breeding lines

\begin{tabular}{lll}
\hline Clone & Percent viable pollen & Percent viable embryo sacs \\
\hline Minn 75-5 & $52.3-81.8$ & 90 \\
Earlaine & $0-69.4$ & 85 \\
Irish Cobbler & $9.1-37.6$ & $60-70$ \\
Sebago & $0-7.4$ & 40 \\
USDA 46000 & $0-5.2$ & 20 \\
Early Ohio & No pollen & 80 \\
Russet Burbank (Netted Gem) & No pollen & 0 \\
\hline
\end{tabular}

Data from Arneson, 1943 
Table 4 Calculated and actual seeds per berry (S/B) in diploid crosses between the same female parent and pollen differing in percent germination in vitro

\begin{tabular}{lll}
\hline Pollen germination & calculated S/B & actual S/B \\
\hline 5 & 81 & 120 \\
6 & 98 & 68 \\
6.5 & 106 & 56 \\
8 & 130 & 60 \\
10.5 & 171 & 89 \\
12.2 & 198 & 78 \\
17.5 & 284 & 125 \\
19.5 & 317 & 77 \\
20.5 & 333 & 37 \\
23 & 374 & 124 \\
24.5 & 398 & 71 \\
25.5 & 414 & 68 \\
26.5 & 431 & 90 \\
34 & 553 & 82 \\
37.5 & 609 & 109 \\
41.5 & 674 & 109 \\
45.5 & 739 & 143 \\
49 & 796 & 117 \\
\hline
\end{tabular}

Data from Janssen and Hermsen 1976

predicted. The actual number of seeds per berry was the same for both the pollen with the highest germination (49\%, 117 seeds) and that with the lowest germination (5\%, 120 seeds). Since the same female clone was used for all pollinations, these data suggested that ovule fertility, incompatibility or embryo abortion may have limited seed production.

\section{Bud Abscission}

"Premature abscission constitutes a very effective type of sterility since it is obvious that buds which fall before opening or flowers which persist for only a few hours cannot produce fruit." (Stevenson and Clark 1933).

Failure to set seed may be due to bud abscission. Buds of all ages commonly fall from potato plants prematurely (Fitch 1910; Dorsey 1919; Ellison 1936; Krantz et al. 1939; Clarke et al. 1941; Arnason 1943). This is unusual. In most plants, unfertilized flowers fall off after they mature. There are typically 15 buds in a young inflorescence, but rarely more than 10 develop into open flowers, even in male fertile varieties (Arnason 1941). In studies of 721 (East 1908b), 676 (Gopal 1993) and 200 (Birhman and Kaul 1989) genotypes grown in the field, $67 \%, 31 \%$, and $41 \%$, respectively, exhibited bud abscission that prevented flower production. Fertilization usually inhibits any further tendency of the flower to drop (Krantz and Hutchins 1929).

Bud abortion is sometimes called blasting and is characterized by the cessation of growth, yellowing, and wilting (Young 1923). Before the flowers fall off, the abscission layer in the pedicel swells and the pedicel turns yellow. In some instances, buds do not develop past a rudimentary stage, while in others the buds develop but they fall off before the flowers are fully mature. For example, in Russet Burbank (Netted Gem), which does not typically produce berries, pedicel abscission led to bud drop, so few open flowers were observed (Arnason 1943).

Bud abscission is influenced by both genotype and environment (Black 1930). An unfavorable environment during the early stages of spore development will likely affect both the male and female parts as sporogenous tissue collapses and disintegrates (Young 1923). Arnason (1941) reported that buds of Early Ohio fell off before flower opening except in cool, moist conditions, when many open flowers were formed. Patterson (1953) suggested that high temperatures may accelerate abscission in flowers of some varieties. Alternatively, nitrogen stores may be more rapidly depleted at high temperatures. Patterson noted that it is common practice to apply nitrogen fertilizer in orchards just prior to bud opening in order to increase fruit set. Haynes and Haynes (1988) reported that cool night temperatures $\left(10^{\circ} \mathrm{C}\right)$ inhibited bud initiation for clones from a diploid hybrid population of $S$. tuberosum subsp. phureja and S. stenotomum. When buds were formed under these conditions, most aborted.

\section{Competition between Flowers and Tubers}

"It is a common idea that the potato does not set fruit as freely now as formerly, and the explanation has been given that the production of large quantities of tubers has led to the degeneration of the seeding power." (East 1908a).

There is a belief, dating back to the work of Knight (1812), if not further, that selection for high tuber yield has resulted in selection against profuse flowering (Krantz et al. 1939; Arnason 1941). Developing flower buds and tubers both rely on photoassimilates produced by leaves and soil nutrients for growth. The hypothesis put forth was that as tubers become stronger sinks for the products of photosynthesis and nutrients, developing inflorescences received less of these essential resources and fewer flowers are produced. Multiple lines of evidence support this hypothesis. For example, in the early nineteenth century, Knight was able to induce early varieties to flower by removing young developing tubers (Knight 1812). Fitch (1910) noted that "tuber productiveness of Pearls is inversely proportionate to the sexual development of the plant; that the most degenerate tuber is grown by the plant which carries fully developed flowers and fertile 
pollen... and that the best tubers and the largest yield are produced by the type of plant whose buds do not even swell." In this case, tuber yields were affected by varying degrees of virus infection. Bud development progressed further and flowers were more numerous on plants when tuber production was impaired by the virus.

Additional research has been carried out to test the hypothesis that berries and tubers compete for resources. In one study, three treatments were applied: (1) plants were cross pollinated daily to maximize berry set, (2) flowers were allowed to develop but were picked three days after opening to prevent berry set and (3) all buds were removed (Bartholdi 1942). Treatments 1 and 2 resulted in yield reductions of $23 \%$ and $10 \%$, respectively compared with treatment 3 . Thus, the author concluded that there is likely competition for nitrogen and carbohydrates between buds/berries and tubers.

Potato breeders commonly use techniques to restrict the allocation of photosynthates to tubers in order to enhance flower production. These techniques include grafting onto tomato, planting on bricks, and stem constriction (Thijn 1954). Another option is "decapitation," in which flowering stems are cut, placed into jars of water, and then pollinated (Peloquin and Hougas 1959). In support of these breeding practices, a negative relationship has been reported between flower and tuber production (Proudfoot 1965; Jansky and Thompson 1990). It is important to note that the same relationship does not necessarily hold for vegetative (vine) and reproductive (flower) growth. In the Lookout Mountain cultivar, there was a strong positive correlation between vegetative growth and seed production (Young 1922) and in openpollinated seedlings of Lookout Mountain, the highest tuber yield was associated with the most vigorous vine growth and largest seed production (Newman and Leonian 1918). Furthermore, based on genomics data, Hardigan et al. (2017) showed that selection for asexual reproduction of cultivars reduced sexual fertility.

Early varieties produce fewer flowers than mid- and lateseason ones (Ellison 1936) and this observation suggests that a large percentage of photoassimilates is directed toward tuber rather than flower development in early varieties compared with mid-season or late varieties. In a stem competition study, Atzimba, the earliest cultivar in the study, had the lowest biomass and the fewest number of flowers, while the latest maturing cultivar, Renacimiento, had the strongest shoot development and the most flowers per plant (Almekinders 1991). In a similar vein, a very early maturing line selection of Triumph rarely produced mature flowers, unlike the original later-season cultivar (Werner 1941a). The most extensive flower and seed production is seen on the first inflorescences formed by a plant, which is consistent with the idea that tubers become stronger sinks over time (Almekinders and Wiersema 1991). Vegetative growth and developing berries can also compete against the initiation of new inflorescences.
Increased stem density was found to reduce the number of flowers per inflorescence (Almekinders 1991).

Recent research is beginning to reveal a putative molecular mechanism for the competition between tubers and reproductive structures for assimilates. In one study that used tuber removal and transgenic lines under- and over-expressing StSP6A, the tuber-inducing signaling protein StSP6A was found to impair flower bud development rather than the tuber sink itself (Plantenga et al. 2018). StSP6A has also been shown to reduce sucrose export from the phloem to the apoplast. Thus, the signal for tuberization increases the percentage of photosynthate transported through the symplast to tubers and decreases the percentage available to other parts of the shoot system (Abelenda et al. 2019). It seems plausible, therefore, that this signal for tuber formation directly reduces the availability of sucrose for developing buds, flowers and berries. A link between bud initiation and sugar signaling, however, has not been clearly demonstrated (Plantenga et al. 2019).

\section{Cytoplasmic Male Sterility}

"Pollen sterility factors associated with $\mathrm{T}$ type cytoplasm may contribute to the narrowness of the genetic base of potato and are a severe constraint in potato breeding." (Powell et al. 1993).

Cytoplasmic male sterility (CMS) is a maternally inherited trait caused by interactions between mitochondrial genes in the egg and nuclear genes in the pollen that leads to defects in anthers or pollen (Anisimova and Gavrilenko 2017). Reciprocal crosses produce normal anthers and pollen. Several research groups have characterized types of cytoplasm in a wide variety of cultivars. Most North American and European cultivars contain "Tuberosum" (T/beta) cytoplasm (Powell et al. 1993; Provan et al. 1999; Hosaka and Sanetomo 2012; Mihovilovich et al. 2015; Sanetomo and Gebhardt 2015; Anisimova and Gavrilenko 2017; Smyda-Dajmund et al. 2020). It seems likely that $T$ cytoplasm was introduced into cultivated potatoes in the nineteenth century when potatoes cultivated in the Northern hemisphere were crossed to landraces from Southern Chile (Grun 1990; Powell et al. 1993; Provan et al. 1999). While this may have led to yield enhancements in progeny, it also resulted in CMS due to interactions between $\mathrm{T}$ cytoplasm and nuclear genes. Consequently, the introduction of this exotic germplasm, most notably the cultivar Rough Purple Chili and its descendants Garnet Chili and Early Rose, likely led to many of the fertility problems mentioned by early twentieth century breeders, including failure of the anther pore to open (Halsted 1890; Grun 1970; Grun et al. 1977; Provan et al. 1999). In addition, in the mid-twentieth century, S. stoloniferum was widely used as a source of potato virus $Y$ resistance. The W/gamma cytoplasm 
carried by $S$. stoloniferum introduced another source of sensitive cytoplasm, leading to pollen sterility (Ross 1986). In this case, tetrads of microspores fuse instead of separating after meiosis (Abdalla and Hermsen 1971). S. demissum was used extensively in breeding programs as a source of late blight resistance. It carries D cytoplasm which causes another form of CMS in which the pollen looks normal but is not viable (Sanetomo and Gebhardt 2015). Segregation for male sterility has been observed in hybrids between dihaploids carrying $\mathrm{T}$ cytoplasm and some wild potatoes (Hermundstad and Peloquin 1985; Jansky and Peloquin 2005). We hypothesize that, in these cases, the wild relative carries a dominant allele of a male sterility $(M s)$ gene that interacts with the $\mathrm{T}$ cytoplasm.

\section{Pollination of Immature Buds}

"When the stigma is receptive (sticky), dust on the pollen collected from the "sire" plant with a camel's hair brush. This pollination should be repeated on two successive days, if the pistil has not fallen." (East 1908a).

Especially in tetraploid varieties, which are self-compatible, breeders are likely to emasculate unopen flowers and pollinate them immediately afterward. This practice may limit pollination success. Pollinations made one day after emasculation of young buds (1-2 days prior to anthesis) are much more successful ( $21 \%$ berry set) than those made on the day of emasculation (5\% berry set) (Henderson and LeClerg 1943). Similarly, berry set and seeds per berry were found to be low when buds were pollinated $48 \mathrm{~h}$ before opening. Berry set was similar for buds pollinated the day before or the day of opening, but seed set was higher in pollinations on open flowers (Bienz 1958). It is important to note that the process of emasculation may damage flowers and reduce berry set (Bamberg 2020).

Pollinations made on young buds may fail to produce abundant seeds for two reasons. Pollen may not germinate on the stigma, and ovules may not be mature when pollen tubes reach them. East (1908a) suggested that pollination success is highest on the day after a flower opens because there is more stigma exudate to stimulate pollen germination. This seems to be supported by the observation that most pollen grains germinate after the flower opens regardless of when the pollen is applied (Bienz 1958). Consequently, pollen tubes do not grow down the style until after the flower opens. Pollen applied to a stigma requires 1.5-2 days to reach the ovule. Only $13 \%$ of ovules are mature on the day of anthesis, so if pollinations are made a day or two before anthesis, then only a small proportion of ovules will be ready to receive the male gametes (Olson 1987). In contrast, $38 \%$ and $75 \%$ of ovules are mature two and three days after anthesis, respectively.

\section{High Temperature}

"Although some varieties blossom more profusely than others, all varieties usually either fail to bloom at all or else produce only a few buds during hot seasons." (Hardenburg 1933).

Potato is native to the Andes Mountains, where summer days are cool and bright sunshine lasts about $12 \mathrm{~h}$ per day. Early researchers appreciated that moving potato from its ancestral home to vastly different growing environments had consequences for potato fertility. "In widely extending the cultivation of the potato, the plant is now often grown under environmental conditions that do not admit of flower formation. The fruitlessness involved in the nonflowering habit and the abscission of flowers is to be regarded as a direct influence of environment. It is, an acquired or enforced sterility" (Stout and Clarke, 1924). By comparing flower, pollen and seed production at various locations and across years, it became apparent that the growing location had a pronounced effect on potato fertility (East 1908a; Stout and Clark 1924; Krantz 1929; Arnason 1943). Stout and Clark (1924) provided compelling evidence for this. They noted that none of 30 standard varieties grown in 1920 and 1921 at the New York Botanical Garden flowered but the same varieties "bloomed in profusion" in the cooler conditions at Presque Isle, Maine. "The first condition necessary for the successful breeding of the potato is that of certain and profuse blooming, and it is useless to undertake breeding unless the environmental conditions strongly favor the development of flowers." (Stout and Clark 1924). A wealth of data collected over many years has shown unambiguously that high temperature is the largest environmental contributor to reduced fertility in potato. This fact was highlighted by Stevenson and Akeley (1947) when they wrote "Many people who live in the South or where the climate is hot and dry have never seen a seed ball growing on a potato plant, and not a few are quite surprised when they first discover one. In cool, long day climates, on the other hand, some sorts produce many seed balls." Percent stainable pollen decreased with increasing temperature, and pollinations carried out in the field were typically less successful later in the season when temperatures are higher (13.7\% on August $6-10$ vs 58.9\% July 23-31 in Minnesota) (Krantz et al. 1939). In Louisiana, field grown plants from the spring crop produced few flowers and the pollen was mostly inviable; fall-grown plants flowered profusely with high pollen germination (King 1955a). In this case, the warming temperatures during plant development in the spring were detrimental to pollen development, while cooling temperatures in the fall enhanced male fertility. Similarly, in the greenhouse, cool temperatures 
promote the development of viable pollen. Russet Burbank is widely known to be male sterile, but it was induced to produce pollen in a winter greenhouse by growing plants at $20-21^{\circ} \mathrm{C}$ until bud formation and then transferring them to a $10-16{ }^{\circ} \mathrm{C}$ greenhouse for bud development (Patterson 1953).

High temperature leads to pollen sterility, as indicated by the pioneering work of Stow (1926) who showed that at 25$30^{\circ} \mathrm{C}$, reduction division of pollen mother cells became irregular and chromosomal abnormalities occurred. At temperatures less than $20^{\circ} \mathrm{C}$, however, meiosis proceeded normally. In the Sebago variety, day/night greenhouse temperatures above $21 / 10^{\circ} \mathrm{C}$ caused a severe decline in the production of viable pollen (Williams 1954).

The detrimental effects of high temperature on potato fertility go beyond their influence on pollen formation. Stout and Clarke (1924) and Krantz (1929) observed that the abscission of flower buds and flowers is responsive to environmental influences. To reduce bud abscission, which was extensive in St. Paul, Minnesota, Krantz established a potato breeding site at Duluth, Minnesota, where temperatures were lower and fertility was much improved. Ellison (1936) observed that high temperature brought about the abscission and inferior development of flower buds, even in cases where it did not affect meiosis.

Arnason (1943) evaluated female fertility in six tetraploid lines across two years in the field in Saskatoon, Saskatchewan, where the daily temperature ranged from 15 to $21^{\circ} \mathrm{C}$ and never exceeded $24{ }^{\circ} \mathrm{C}$. More berries and seeds were produced in 1942 than 1941. When berries were forming in July, the average temperature was above $21{ }^{\circ} \mathrm{C}$ for 18 days in 1941 but only for one day in 1942 . The range of seeds per berry in 1941 and 1942, respectively, was 0-183 and 7-472. The most common number of seeds per berry in 1941 and 1942, respectively, was 20-100 and 100-300. Temperatures above $21{ }^{\circ} \mathrm{C}$, then, inhibited both berry set and seeds per berry. In a greenhouse trial in April in Ithaca, New York, temperature was recorded throughout the pollinating season (Bienz 1958). The greenhouse temperature was set at $18^{\circ} \mathrm{C}$ and it remained below $21^{\circ} \mathrm{C}$ except on sunny days, when it reached as high as $38^{\circ} \mathrm{C}$. Heat units per day were calculated based on a threshold temperature of $21^{\circ} \mathrm{C}$. During the period from $24 \mathrm{~h}$ preceding to $96 \mathrm{~h}$ following pollination, heat units were significantly negatively correlated $(r=-0.88)$ with berry set. High temperature on a single day had no discernable effect on berry set, but berry set was reduced when the temperature was above $21{ }^{\circ} \mathrm{C}$ for a few days before and after flower opening.

Many wild species relatives of cultivated potato also have reduced fertility when exposed to high temperatures, but there are exceptions. In one study, $S$. commersonii, S. jamesii, S. kurtzianum and S. megistacrolobum flowered extensively and shed viable pollen despite exposure to high temperatures in a greenhouse (Bamberg 1995).

\section{Insufficient Light}

"The longer photoperiod favors the production of mature flowers, but this is because the abscission of young buds is reduced." (Clarke and Lombard 1942).

As early twentieth century potato breeders looked for ways to increase the fecundity of their breeding stocks, they explored options for making crosses in greenhouses rather than in the field. This allowed them to avoid infertility caused by summer heat. Growth of potatoes in winter greenhouses, however, posed other challenges and raised additional questions, especially about the light environment. Stevenson and Clark (1933) conducted a winter greenhouse trial to optimize true seed production at Arlington Farm, Virginia. They observed that supplemental, artificial lights stimulated vine growth and blossoming to a remarkable degree. Their light treatments were (1) no artificial light, (2) 500-watt lamp with an $18 \mathrm{~h}$ photoperiod and (3) 1000-watt lamp with an 18 hour photoperiod. The percentage of clones that flowered for treatments 1, 2, and 3 was 5, 68 and 73, respectively. Werner (1941b) also found that flower and berry production in a winter greenhouse were stimulated by increased light intensity, either with artificial lights or by planting later (December 24 rather than December 9) to provide higher average daily radiation during flowering. Similarly, lengthening the light period led to more flower and berry development (Werner 1941a). Surprisingly, plants grown under $24 \mathrm{~h}$ light throughout their life span produced the most berries in these experiments.

Photoperiod is often reported to have a large effect on flower production, and the effect of photoperiod on potato fertility has been examined by several researchers. In one early trial, potatoes were grown with photoperiods of 9,1113 and $17 \mathrm{~h}$ by supplementing natural light in a greenhouse with artificial lights (Edmundson 1941). Bud abscission decreased dramatically with longer photoperiod, especially with $17 \mathrm{~h}$ of light, and the number of seedballs and weight of seeds increased. Photoperiod, however, had little effect on percent stainable pollen. Stevenson (1945) described research by Driver and Hawkes who observed that short days reduced flower formation, even though flowering is extremely abundant in the Andes mountains under short-day conditions. They suggested that flowering is more dependent on the quantity of light received than on the length of the day.

Jones and Borthwick (1938) also evaluated the effect of two temperature regimes and four photoperiods (supplied by 60-watt Mazda incandescent lamps) on the initiation of flower primordia. A small delay in bud initiation was noted for small seed pieces, high temperature $\left(27^{\circ} \mathrm{C} / 13^{\circ} \mathrm{C}\right.$ vs $\left.21^{\circ} \mathrm{C} / 7^{\circ} \mathrm{C}\right)$ and a short $(9 \mathrm{~h})$ photoperiod. However, flower primordia formed regardless of photoperiod (Jones and Borthwick 1938). The minimum photoperiod and seed piece size for the initiation of flower bud primordia was tested in Chippewa and Earlaine plants that received $0,2,4,6$, and $8 \mathrm{~h}$ of light daily (Jones 
and Borthwick 1938). The $5 \mathrm{~g}$ seed pieces at 0 and $8 \mathrm{~h}$ did not produce flower buds. For other seed piece sizes and photoperiods, flower buds were initiated, even in total darkness. Thus, although photoperiod does not seem to influence the formation of flower bud primordia, it does affect bud and flower development (Edmundson 1941). In a follow-up study, seed pieces of different sizes were grown for three cultivars. Plants were exposed to four light treatments - total darkness, natural light, and natural light supplemented with Mazda incandescent lamps or fluorescent lamps (Clarke and Lombard 1942). Small seed pieces $(5 \mathrm{~g})$ produced plants with far fewer buds than larger pieces ( 25 and $45 \mathrm{~g}$ ). Apparently, some of the reserves contained within the seed piece were needed to initiate buds, but photoperiod did not provide the cue for the transition from vegetative to reproductive growth. Longer photoperiod promoted production of mature flowers, but this was largely because abscission of buds was prevented.

The light experiments described above evaluated the effect of photoperiod on flowering. In all likelihood, however, they revealed the effect of total light energy rather than photoperiod per se on bud and flower development.

\section{Practices that Influence Seed Production}

"Perfection in breeding stock and in varieties may be an infinite aim. This, however, is immaterial as long as progress in the improvement of breeding stock is reflected in the production of better varieties." (Krantz and Hutchins 1929).

Genetic makeup and environmental conditions are the primary determinants of potato fecundity. Those who would produce true potato seeds will, by necessity, consider these factors when making crosses. Other practices employed in potato hybridization also influence the ease or extent of seed production. Research underpinning some of the more common practices is reviewed here.

\section{Collecting Pollen}

"Flowers with plump, bright yellow anthers with a brownish tip are most apt to be good sources of pollen" (Plaisted 1980).

Pollen is collected, and often stored, for use in potato breeding. Potato flowers open fully in the morning and close again in the evening (East 1908a). It has often been observed that pollen is generally most abundant in the morning (Plaisted 1980). Pollen is most easily collected from anthers that have developed a pore at their distal ends. In nature, buzz pollination by bumblebees vibrates the anthers and results in pollen shed from the pore. Potato breeders have discovered that simulating this buzzing of anthers, using a wire attached to the mechanism from a doorbell (Blomquist and Lauer 1962) or with the end of an electric toothbrush (US Potato Genebank
2017), is an effective way to release pollen. Genotypes that contain indehiscence-sensitive cytoplasm do not develop the anther pore and do not shed pollen, even when they produce viable pollen (Grun 1970). In those cases, the tip of the anther can be cut off or the anther can be split open to facilitate pollen collection. If pollen is to be used immediately, it can be collected on a fingernail, forceps, glass slide or other surface (Salaman 1920; Stuart 1928; Bienz 1958) and then transferred it to the stigma. If pollen is to be stored, it can be collected directly into a small vial or gelatin capsule (Bloomquist and Lauer, 1962; Plaisted 1980). Alternatively, some researchers harvest anthers and use them as a source of pollen after they are dried (Howard 1958).

\section{Pollen Storage}

"The importance of a knowledge of the handling of pollen for pollination purposes has long proceeded the actual accumulation of that knowledge." (King 1955b).

There are two types of pollen storage, (1) short-term while being used for pollinations and (2) long-term without being removed from storage (King 1955b). Regardless of how long it will be stored, it is important to collect pollen with the highest viability possible. Viability of pollen from buds just before opening was lower than that from flowers that had been open for 2-3 days (Edmundson 1939). Pollen may deteriorate considerably after the flower has been open for 5-6 days (Salaman and Lesley 1922). In vitro germination of pollen stored at room temperature and ambient humidity dropped considerably after one day and fell to zero after two days (Janssen and Hermsen 1976).

It appears that the easiest and best way to store pollen for both the short and the long term is in a freezer. The number of berries and seeds per berry produced were similar when crosses were made with fresh pollen or pollen that had been desiccated and stored for 9 or 11 months at $-20{ }^{\circ} \mathrm{C}$ (Howard 1958; De Maine 1977). In another study, the viability of pollen stored over desiccant at $-15{ }^{\circ} \mathrm{C}$, measured as seeds per berry, decreased almost linearly from one month to five years of storage (De Maine, 1988). Although the number of seeds per berry dropped by $30 \%$ after one month of storage, some seeds were still produced with 5 -year-old pollen.

Blomquist and Lauer (1962) carried out a series of pollen storage studies to mimic practices used by breeders. Pollen viability was measured as number of seeds per berry. Freshly harvested pollen stored at room temperature $\left(25^{\circ} \mathrm{C}\right)$ remained functional for eight days, but in a refrigerator $\left(2.5^{\circ} \mathrm{C}\right)$, it remained viable for at least 31 days. Pollen stored in a freezer $\left(-24^{\circ} \mathrm{C}\right)$ remained viable for a year. There was no consistent benefit of storing pollen over desiccant. In another trial, pollen was periodically removed for four hours and then put back in the refrigerator or freezer to simulate a breeder's 
activities. In the refrigerator, the pollen was viable for at least 15 days, but it was viable for 31 days when stored in the freezer. Apparently, some freeze thaw treatments are not detrimental to pollen.

For very long-term storage, liquid nitrogen offers a viable option. In vitro germination of pollen stored for nine months at $-20{ }^{\circ} \mathrm{C}$ was $29 \%$ of fresh control, but it was the same as the control when stored in liquid nitrogen $\left(-196^{\circ} \mathrm{C}\right)$ (Weatherhead et al. 1978). Similarly, viability of pollen stored in liquid nitrogen for 11 or 24 months was similar to the fresh pollen control (Towill 1984). Drying pollen briefly over anhydrous calcium chloride before freezing in liquid nitrogen was beneficial, but may be harmful if exposure to the drying agent is too long. There is no information that we are aware of on the relationship between very low pollen moisture contents (as happens with long exposure to calcium chloride) and viability. It would be helpful to evaluate other drying agents that equilibrate at higher moisture levels.

\section{Measuring Male Fertility}

"Germination percentages of potato pollens can, therefore, be expected to give an indication that a pollen is living; but the erratic reaction of potato pollen to artificial media make these percentages necessarily not reliable in regard to the actual potency of a pollen at any one time, particularly in view of that potency in pollination." (King and Johnston 1958).

Considering that knowledge of pollen viability is important when choosing parents and when choosing pollen storage methods, there is surprisingly little consensus as to a reliable assay for viability. According to King (1955b) "The pollens of a number of horticultural crops (and certainly those of Irish potato which we have studied so far), however, react irrationally in germination tests for viability." In breeding programs, some level of fertility is often the only criterion for deciding whether to include a certain line in the crossing block. Not all combinations are expected to produce seeds and large seed numbers are not needed to evaluate families. However, with renewed interest in the development of varieties that will be propagated from true seed, it is becoming more important to develop reliable pollen viability tests.

The gold standard for pollen viability and "potency" is the ability to produce seeds when used in crosses. However, this is a time- and resource-consuming process and results can be confounded by the environment and the genotype of the female parent. Even if pollination environment and female fertility are accounted for, data sets accumulated across time are not comparable because pollen viability varies among samples collected from different flowers and on different dates (Janssen and Hermsen 1976; Arndt et al. 1990).

An alternative measure of pollen viability is in vitro pollen germination, which measures the ability of pollen tubes to grow in an artificial environment. The pollen is germinated on an agar medium or a hanging drop slide. The germinating pollen can be directly viewed under a microscope, allowing the behavior of the pollen to be observed. East (1908b) noted that multiple pollen tubes can grow from one pollen grain and suggested that these pollen grains contain several nuclei. Berry production was much more successful with a high proportion of multinucleate pollen grains. In addition, he suggested that pollen with protuberances at the pores germinate earlier and grow faster than those with a smooth outline.

Pollen is typically germinated in a medium containing, at a minimum, a sugar and boron. Rehydration of pollen is needed for maximum germination in in vitro assays (Towill 1984). Favorable conditions for in vitro pollen germination are a solution of $20 \%$ sucrose plus 50 ppm boric acid (Mortenson et al. 1964), pH 5.2 (King and Johnston 1958) and a temperature of $16-21^{\circ} \mathrm{C}$ (King and Johnston 1958). Bamberg and Hanneman (1991) found that lactose is preferable to sucrose for these assays. Pollen germinates within two hours and is typically observed after a 5-24 h incubation period (King and Johnston 1958; De Maine 1977; Trognitz 1991). It is important to maintain high humidity while the pollen is germinating to reduce evaporation from the incubation medium (King and Johnston 1958; Mortenson et al. 1964). Mortenson et al. (1964) found that pollen will not germinate if the population of pollen grains is too small. In a $10 \mu \mathrm{l}$ drop, 300 pollen grains were needed for any pollen to germinate; maximum germination occurred when 2000 grains were present. It is thought that calcium and other compounds released by pollen support germination. An improved in vitro germination medium includes calcium, potassium and magnesium in addition to sucrose and boron, and $\mathrm{pH}$ is adjusted to 5.5 (Pallais et al. 1984). This formulation may allow low numbers of pollen to be evaluated.

Although in vitro pollen germination studies have been carried out for over a century, there is still a lack of confidence in test results. Pollen germination is influenced by the composition of the germination medium, including osmotic properties and $\mathrm{pH}$ and, consequently, may give erratic results unless the medium is optimized for each sample (King 1955b; King and Johnston 1958; Mortenson et al. 1964). According to King and Johnston (1958) "a consistent characteristic of the pollen grain as a biological unit seems to lie in its inconsistency in response, by germination, to an artificial environment." Consequently, pollen germination tests may be useful for determining whether pollen is viable, but less reliable for predicting potency for seed production.

In vitro germination tests appear to underestimate the ability of a pollen sample to produce offspring (King 1955b). Genotypes with as little as $2 \%$ in vitro pollen germination can function as male parents (Mortenson et al. 1964). However, Janssen and Hermsen (1976) reported that in vitro germination correlated with berry $(r=0.92)$ and seed set $(r=$ 0.68). Other variables that affect pollen germination were 
noted by Mortenson et al. (1964). For example, pollen collected before anthesis did not germinate and germination was reduced in pollen from closed or abscised flowers. Flowers picked $24 \mathrm{~h}$ before testing also had lower percent germination scores than freshly picked flowers. These observations likely reflect actual changes in viability, but this assumption has not been tested.

Finally, direct microscopic observation of pollen grains is the easiest and arguably the most widely used measure of pollen viability. The first studies of pollen viability in the early twentieth century observed pollen grains placed in water. Viable grains swell and become spherical and translucent with prominent pores, while inviable pollen is smaller, irregular, and appears empty (Salaman and Lesley 1922). Later, histological stains were more commonly used. However, according to King (1955a), stains such as acetocarmine and 2, 3, 5triphenol tetrazolium chloride "only help to show more clearly that which is already obvious," an observation reinforced in a recent publication showing that pollen swelling in water was a good indicator of viability (Kramer and Bamberg 2019).

Opinions vary widely on of the value of estimating pollen viability based on the appearance of pollen grains. King (1955b) suggested that observations of stained pollen are "meaningless" as a measure of pollen potency. For example, in a study of 16 dihaploids, the three with the highest stainability estimates (49-56\%) produced no berries, while the clones with the highest berry set (26 per/100 pollinations) produced $20 \%$ stainable pollen, while that with the highest seed set (30 seeds per berry) produced $14 \%$ stainable pollen (Carroll and Low 1976). However, according to Fineman (1947), sterile pollen can be readily and consistently distinguished from fertile pollen when stained with acetocarmine and observed under a microscope. Inviable pollen is generally small $(20 \mu \mathrm{m})$ (East 1908b), collapsed, irregular in shape, sometimes present in pairs, and low in abundance, while viable pollen is abundant, round and plump, and $35-50 \mu \mathrm{m}$ in diameter (pollen from tetraploids) (East 1908b; Fineman 1947). When stained with acetocarmine, nonviable pollen may be shrunken and wrinkled or may stain lightly or have pockets of lightly staining regions (Henderson and LeClerg 1943; Ordoñez et al. 2017)). It is apparent that not only the intensity of staining, but the shape and size of pollen grains must be considered.

While in vitro germination may underestimate pollen viability, stainability may overestimate it (Ordoñez et al. 2017). Percent stainable pollen is typically higher than the percent of pollen grains that germinate in vitro (Mortenson et al. 1964; Janssen and Hermsen 1976). Pollen that takes up acetocarmine stain may include viable grains that do not germinate in vitro and normal looking grains with dead cytoplasm; pollen from old plants or old flowers, and improperly stored pollen may be highly stainable but does not germinate in vitro (Janssen and Hermsen 1976). In that study, acetocarmine stainability did not correlate with seed or berry set.

Enzyme assays offer an alternative to pollen staining (Trognitz 1991). Examples include fluorescein diacetate (FDA), 2-3-5 triphenyl tetrazolium chloride (TTC), and 5bromo-4-chloro-3-indolyle-beta-galactoside (X-Gal). Each assay tests for pollen enzymatic activity as a measure of viability. In a comparison of FDA, TTC, and X-Gal, FDA produced the strongest correlation with in vitro germination $(\mathrm{r}=$ $0.86)$. The correlation between germination and acetocarmine staining was lower $(r=0.68)$ but highly significant.

Breeders have noted that pollen abundance is often positively associated with viability (Salaman 1910; Salaman and Lesley 1922; Arnason 1941; Henderson and LeClerg 1943). When pollen abundance is low, it is almost always inviable. When comparing clones with low versus high pollen shed, Janssen and Hermsen (1976) reported that percent stainable pollen averaged 32 versus $81 \%$ while percent in vitro germination was 1 and 19\%, respectively. However, there are examples of abundant pollen shed and low viability (Salaman 1910). A modern example is DM1-3, the diploid genotype on which the potato genome is based.

Pollen stainability of field-grown varieties can vary considerably over years (Arnason 1941; Henderson and LeClerg 1943) and, across environments, appears to be more stable in some genotypes than others (Carroll and Low 1976; Arndt et al. 1990). However, when conditions for flowering and fruit setting are favorable, pollen stainability can be consistent across years and locations (Fineman 1947).

With all viability tests, an important question is whether there is a threshold or optimal score that predicts pollination success. According to Mortenson et al. (1964), as little as $2 \%$ in vitro pollen germination is needed for functional male fertility. There is no consensus, though, on pollen stainability scores needed for successful berry set. East (1908b) suggested that pollination success is very low if pollen viability based on microscopic examination of pollen grains is less than $25 \%$. However, Edmundson (1939) argued that Bliss Triumph and Irish Cobbler are fertile even though they have very low stainable pollen (Edmundson 1939). This observation is supported by Arndt et al. (1990), who reported seed set with stainability scores as low as $1 \%$ (Table 5). Krantz et al. (1939) found a relationship between pollen stainability and berry set, but over half of the pollinations produced berries even with less than $5 \%$ stainable pollen (Table 6).

\section{Breeding for Fertility}

"The progeny of parents which are themselves scant seed setters usually contain a very high percentage of non-seed producing individuals." (Krantz 1929). 
Table 5 Relationship between pollen stainability with acetocarmine and seeds per berry $(\mathrm{S} / \mathrm{B})$ in 12 clones. Data are highest stainability score and season average score for percent stainable pollen across seven dates in a season and average number of seeds per berry $(\mathrm{S} / \mathrm{B})$

\begin{tabular}{lll}
\hline High & Average & S/B \\
\hline 3 & 1 & 32 \\
3 & 2 & 86 \\
6 & 2 & 48 \\
7 & 5 & 90 \\
7 & 3 & 107 \\
8 & 4 & 108 \\
9 & 3 & 85 \\
10 & 8 & 57 \\
18 & 8 & 120 \\
22 & 9 & 149 \\
25 & 13 & 200 \\
30 & 16 & 137 \\
\hline
\end{tabular}

Data from Arndt et al. 1990

The male fertility of clones used as female parents in breeding programs can have a significant impact on the male fertility of offspring. When male sterile plants were used as female parents, a large proportion of offspring were male sterile (Krantz 1924). In a later study using reciprocal crosses between plants with high and low male fertility, there was a consistent effect of the female parent on male fertility of the offspring (Fineman 1947). When a clone with low pollen fertility was used as a female parent, a higher percentage of offspring were male sterile than when it is was used as a male parent. Perhaps the factors responsible for pollen sterility are eliminated in aborted pollen but not eggs (Salaman and Lesley 1922; Fineman 1947). It is important to note that the male parent may also influence the male fertility of progeny.

Many parents in breeding programs are male sterile, so they are used as females in crossing blocks. However, since male sterility is passed on to offspring through the female

\begin{tabular}{|c|c|c|}
\hline \multirow{12}{*}{$\begin{array}{l}\text { Table } 6 \text { Relationship } \\
\text { between acetocarmine } \\
\text { staining and percent } \\
\text { plants that produced } \\
\text { berries }\end{array}$} & Stainability & Berry se \\
\hline & $0-5$ & $55 \%$ \\
\hline & $5-10$ & 76 \\
\hline & $10-20$ & 78 \\
\hline & $20-30$ & 76 \\
\hline & $30-40$ & 80 \\
\hline & $40-50$ & 94 \\
\hline & $50-60$ & 93 \\
\hline & $60-70$ & 95 \\
\hline & $70-80$ & 98 \\
\hline & $80-90$ & 100 \\
\hline & $90-100$ & 100 \\
\hline
\end{tabular}

Data from Krantz et al. 1939 parent though various forms of CMS, a large proportion of progeny will be male sterile. If a male sterile clone is used as a female parent in a breeding program and then selection is based mainly on tuber production, it is likely that by chance the selected clones will contain $\mathrm{T}$ cytoplasm and will be male sterile. In contrast, if partially male fertile plants are used as female parents, then a larger proportion of offspring will be male fertile and selections based on tuber traits are more likely to be male fertile.

Several breeding options exist to overcome CMS in potato. Breeders could use exotic germplasm carrying fertile $\mathrm{P}$ or A type cytoplasm as female parents. There is a welljustified reluctance to do this, however, given that such crosses often introduce numerous commercially undesirable traits. Another way to avoid CMS is to use lines that carry $\mathrm{T}$ cytoplasm only as male parents. Obviously, this is difficult, given that male sterility is widespread in potatoes with T cytoplasm, although there are exceptions (Mihovilovich et al. 2015). Perhaps over time, male fertility could be improved by using this approach. Recent trends have not been altogether encouraging. The percentage of breeding lines with $\mathrm{T}$ cytoplasm has decreased relative to traditional varieties, but the percentage of breeding lines with $\mathrm{W}$ and D cytoplasm has increased (Mihovilovich et al. 2015; Sanetomo and Gebhardt 2015). An alternative approach is the introduction and fixation of the dominant fertility restorer $(R t)$ gene identified by Iwanaga et al. (1991). This would restore fertility even in sensitive cytoplasm carrying $M \mathrm{~s}$, a dominant gene that interacts with $\mathrm{T}$ cytoplasm and causes male sterility. This latter system may also be useful for the large-scale production of true potato seed, following models in other crops such as eggplant and pepper (Anisimova and Gavrilenko 2017).

Perhaps as diploid hybrid breeding programs develop, they can use male sterility to their advantage. Crossing a male sterile inbred line to male fertile inbred lines would produce male sterile F1 hybrids. The lack of berry production in the hybrids would eliminate the competition for photosynthates mentioned above and may promote high yields. It would also avoid concerns about weediness in a crop generated from true potato seed (Lawson 1983).

\section{Final Thoughts}

A century of research on potato fertility has revealed much about the genetic and environmental contributors to low fecundity in this crop. The varieties that we grow today contain in their DNA a genetic record of potato breeding, especially since the 1860 's. Traits that were introduced to meet the needs of the potato industry, high yield and disease resistance in particular, brought with them a notable 
reduction in fertility that continues to create challenges for potato breeders today. To some extent, the sources of infertility have been identified and there are potato breeding approaches that may alleviate the deleterious effects of CMS and the propagation of impaired male fertility. Removing the environmental constraints on potato fertility is easier than alleviating the genetic constraints. Temperature-controlled greenhouses equipped with high intensity lights can be used to create an environment favorable for crossing potatoes anywhere, at any time of year. Suggested 'best practices' that contribute to seed production in potato are outlined in Table 7. It is our expectation that potato breeding will rely increasingly on targeted breeding strategies informed by molecular analysis. Parents will be selected because they have complementary alleles. Breeding practices that promote successful seed production by removing genetic and environmental constraints to fertility will pay dividends in the ease and efficiency of implementing molecular potato breeding.

Table 7 Recommended breeding practices that promote potato fertility and seed production

\section{Enhancing flower production}

1. Provide a photoperiod of at least $16 \mathrm{~h}$

2. Maintain high light intensity to reduce bud abscission

3. Grow plants in large pots with adequate spacing to minimize shading

4. Apply an appropriate amount of fertilizer with proper timing; responses vary by variety; fertilize heavier than needed for tuber production $^{\mathrm{a}, \mathrm{b}}$

5. Plant large seed pieces (at least $45 \mathrm{~g}$ )

6. Maintain cool temperatures, e.g. $20{ }^{\circ} \mathrm{C}$ day, $17{ }^{\circ} \mathrm{C}$ night

7. Never exceed $24^{\circ} \mathrm{C}$, a goal that is easier to achieve in the winter

8. Potting soil should be uniformly moist. Never allow plants to wilt

9. Spraying young inflorescences with $200 \mathrm{ppm}$ gibberellic acid can increase the number of flowers and the amount of pollen produced ${ }^{\mathrm{a}}$

10. For recalcitrant genotypes, induce flowering by grafting on tomato, double grafting, or removing developing tubers ${ }^{c}$

Collecting and storing of pollen

1. Collect pollen from young flowers (1-4 days post-anthesis)

2 . For some genotypes, it is easier to collect pollen from flowers that have been picked and allowed to dry for up to a day

3. Immediately store pollen in a freezer (desiccation is not necessary)

Pollinating flowers

1. Pollinate the first inflorescence on each stem ${ }^{\mathrm{d}}$

2. Pollinate the first six buds on the inflorescence; remove all others ${ }^{4}$

3. Pollinations can be made at any time of the day ${ }^{\mathrm{e}}$

4. Do not rehydrate pollen after storage ${ }^{\mathrm{f}}$.

5. Cross pollination in a greenhouse is uncommon if plants are not shaken while flowering and pollen is applied with care; self-pollination is common with highly fertile varieties.

6. Wait until berries begin to develop before covering with cheesecloth or mesh bags.

${ }^{\text {a }}$ Pallais et al., 1984

${ }^{\mathrm{b}}$ Pallais, 1987

${ }^{\mathrm{c}}$ Thijn 1954; Upadhya et al. 1985

${ }^{\mathrm{d}}$ Upadhya et al. 1985

${ }^{\mathrm{e}}$ Towill 1984
Funding This work was funded by USDA-NIFA award number 2019-51181-30021.

Open Access This article is licensed under a Creative Commons Attribution 4.0 International License, which permits use, sharing, adaptation, distribution and reproduction in any medium or format, as long as you give appropriate credit to the original author(s) and the source, provide a link to the Creative Commons licence, and indicate if changes were made. The images or other third party material in this article are included in the article's Creative Commons licence, unless indicated otherwise in a credit line to the material. If material is not included in the article's Creative Commons licence and your intended use is not permitted by statutory regulation or exceeds the permitted use, you will need to obtain permission directly from the copyright holder. To view a copy of this licence, visit http://creativecommons.org/licenses/by/4.0/.

\section{References}

Abdalla, M.M.F., and J.G.T. Hermsen. 1971. The plasmon-genic basis of pollen lobedness and tetrad sterility in Solanum verrucosum hybrids and duplicate linkage groups. Genetica 42: 261-270.

Abelenda, J.A., S. Bergonzi, M. Oortwijn, S. Sonnewald, M. Du, R.G.F. Visser, U. Sonnewald, and C.W.B. Bachem. 2019. Source-sink regulation is mediated by interaction of an FT homolog with a SWEET protein in potato. Current Biology 29: 1178-1186.

Almekinders, C.J.M. 1991. Flowering and true seed production in potato (Solanum tuberosum L.). 2. Effects of stem density and pruning of lateral stems. Potato Research 34: 379-388.

Almekinders, C.J.M., and S.G.G. Wiersema. 1991. Flowering and true seed production in potato (Solanum tuberosum L.). 1. Effects of inflorescence position, nitrogen treatment, and harvest date of berries. Potato Research 34: 365-377.

Ames, M., and D.M. Spooner. 2008. DNA from herbarium specimens settles a controversy about origins of the European potato. American Journal of Botany 95: 252-257.

Anisimova, I.N., and T.A. Gavrilenko. 2017. Cytoplasmic male sterility and prospects for its utilization in potato breeding, genetic studies and hybrid seed production. Russian Journal of Genetics Applied Research 7: 721-735.

Arnason, T. 1941. Sterility in potatoes. Canadian Journal of Research 19: $145-155$.

Arnason, T. 1943. Female sterility in potatoes. Canadian Journal of Research 21: 41-56.

Arndt, G.C., and S. Peloquin. 1990. The identification and evaluation of hybrid plants among open pollinated true seed families. American Potato Journal 67: 393-404.

Arndt, G.C., J.L. Rueda, H.M. Kidane-Mariam, and S.J. Peloquin. 1990. Pollen fertility in relation to open pollinated true seed production in potatoes. American Potato Journal 67: 499-505.

Bamberg, J.B. 1995. Screening potato (Solanum) species for male fertility under heat stress. American Potato Journal 72: 23-33.

Bamberg, J. 2020. Emasculation technique reduces seedset in Solanum verrucosum. American Journal of Potato Research 97: 111-113.

Bamberg, J.B., and R.E. Hanneman Jr. 1991. An effective method for culturing pollen tubes of potato. American Potato Journal 68: 373-379.

Bartholdi, W. 1942. Influence of flowering and fruiting upon vegetative growth and tuber yield in the potato. Minnesota Agricultural Experiment Station Technical Bulletins 150: 1-20.

Batra, S. 1993. Male-sterile potato flowers are selectively buzz-pollinated only by Bombus terricola Kirby in upstate New York. Journal of the Kansas Entomological Society 4: 252-254. 
Bienz, D.R. 1958. The influence of environmental factors and pollinating techniques on the success of potato pollination in the greenhouse. American Potato Journal 35: 377-385.

Birhman, R.K., and M.L.H. Kaul. 1989. Flower production, male sterility and berry setting in andigena potato. Theoretical and Applied Genetics 78: 884-888.

Black, W. 1930. Notes on the progenies of various potato hybrids. Journal of Genetics 22: 27-43.

Blomquist, A., and F. Lauer. 1962. A simplified technique for handling and storing potato pollen. American Potato Journal 39: 340-343.

Bradshaw, J.E., and G.R. MacKay. 1994. Breeding strategies for clonally propagated crops. In Potato Genetics, ed. J.E. Bradshaw and G.R. MacKay, 467-497. Wallington, Oxon, UK: CAB International.

Breeze, M. 1921. Degeneration of potato anthers. Gardens Chronicle 70: 274-275.

Carroll, C.P., and R.J. Low. 1976. Aspects of male fertility in group Tuberosum dihaploids. Potato Research 19: 109-121.

Clark, C., W. Stuart, and F. Stevenson. 1931. The Katahdin potato: A new variety. American Potato Journal 8: 121-125.

Clarke, A. 1940. Fertilization and early embryo development in the potato. American Potato Journal 17: 20-25.

Clarke, A., and P. Lombard. 1942. Flower bud formation in the potato plant as influenced by variety, size of seed piece, and light. American Potato Journal 19: 98-105.

Clarke, A., W. Edmundson, and P. Lombard. 1941. Seed-setting in potatoes as affected by spraying with a-naphthaleneacetamide. American Potato Journal 18: 273-279.

De Maine, M.J. 1977. A simple technique for the short-term storage of pollen of a dihaploid-inducing diploid potato clone. The Journal of Agricultural Science 89: 511-512.

Dnyansagar, V., and D. Cooper. 1960. Development of the seed of Solanum phureja. American Journal of Botany 47: 176-186.

Dorsey, M.J. 1919. A note on the dropping of flowers in the potato. The Journal of Heredity 10: 226-228.

East, E.M. 1908a. A study of the factors influencing the improvement of the potato. University of Illinois Agricultural Experiment Station Bulletin No. 127: 375-456.

East, E.M. 1908b. Some essential points in potato breeding. Аnnu. Reports Connect. Agric. Exp. Stn. 31: 429-447.

Edmundson, W.C. 1939. Comparison of Katahdin potato pollen produced in the field and in the greenhouse. American Potato Journal 19: $12-15$.

Edmundson, W.C. 1941. Response of several varieties of potatoes to different photoperiods. American Potato Journal 18: 100-112.

Ellison, W. 1936. Meiosis and fertility in certain British varieties of the cultivated potato (Solanum tuberosum L.). Genetica 18: 217-254.

Fineman, Z. 1947. Elimination and retention of pollen sterility in potato improvement. Journal of Agricultural Research 75: 135-146.

Fitch, C. 1910. Productiveness and degeneracy of the Irish potato. Colorado Agricultural Experiment Station Bulletin 176.

Fukada, Y. 1925. Cytological studies on the development of the pollengrain in different races of Solanum tuberosum L. with special reference to sterility. Botanical Magazine 41: 459-474.

Glendinning, D.R. 1976. Neo-Tuberosum: New potato breeding material. 4. The breeding system of neo-Tuberosum, and the structure and composition of the neo-Tuberosum. Potato Research 19: 27-36.

Glendinning, D.R. 1983. Potato introductions and breeding up to the early 20th century. The New Phytologist 94: 479-505.

Goodrich, C.E. 1863. The origination and test culture of seedling potatoes. Transactions of the New York State Agricultural Society 23: 89-134.

Gopal, J. 1993. Flowering behaviour, male sterility and berry setting in tetraploid Solanum tuberosum germplasm. Euphytica 72: 133-142.

Greiner, S., J. Sobanski, and R. Bock. 2015. Why are most organelle genomes transmitted maternally? BioEssays 37: 80-94.

Grubb, E.H. 1912. The Potato: A compilation of information from every available source. In Doubleday, Page \& Company. Garden: City, NY.
Grun, P. 1970. Cytoplasmic sterilities that separate the cultivated potato from its putative diploid ancestors. Evolution (N. Y). 24: 750-758.

Grun, P. 1990. The evolution of cultivated potatoes. Economic Botany 44: 39-55.

Grun, P., C. Ochoa, and D. Capage. 1977. Evolution of cytoplasmic factors in tetraploid cultivated potato (Solanaceae). American Journal of Botany 64: 412-420.

Gutaker, R.M., C.L. Weiß, D. Ellis, N.L. Anglin, S. Knapp, J. Luis Fernández-Alonso, S. Prat, and H.A. Burbano. 2019. The origins and adaptation of European potatoes reconstructed from historical genomes. Nature Ecology and Evolution 3: 1093-1101.

Halsted, B. 1890. Notes upon the stamens of Solanaceae. Botanical Gazette 15: 103-106.

Hardenburg, E. 1933. Efficiency factors in the cultivation of potatoes. American Potato Journal 10: 94-98.

Haynes, F. 1954. Potato embryo culture. American Potato Journal 31: 282 288.

Haynes, K.G., and F.L. Haynes. 1988. The effect of day and night temperatures on bud initiation and flowering in diploid potatoes. American Potato Journal 65: 589-596.

Henderson, M., and E. LeClerg. 1943. Studies of some factors affecting fruit setting in Solanum tuberosum in the field in Louisiana. Journal of Agricultural Research 66: 67-76.

Hermundstad, S.A., and S. Peloquin. 1985. Male fertility and 2n pollen production in haploid-wild species hybrids. American Potato Journal 62: 479-487.

Hosaka, K., and R. Sanetomo. 2012. Development of a rapid identification method for potato cytoplasm and its use for evaluating Japanese collections. Theoretical and Applied Genetics 125: 1237-1251.

Howard, H.W. 1958. The storage of potato pollen. American Potato Journal 35: 676-678.

Iwanaga, M., R. Ortiz, M.S. Cipar, and S.J. Peloquin. 1991. A restorer gene for genetic-cytoplasmic male sterility in cultivated potatoes. American Potato Journal 68: 19-28.

Jansky, S.H., and S.J. Peloquin. 2005. Advantages of wild diploid Solanum species over cultivated diploid relatives in potato breeding programs. Genetic Resources and Crop Evolution 53: 669-674.

Jansky, S.H., and D.M. Thompson. 1990. The effect of flower removal on potato tuber yield. Canadian Journal of Plant Science 70: 12231225.

Jansky, S., A. Hamernik, and X. Cai. 2012. Rapid cycling with true potato seed. Seed Science and Technology 40: 43-50.

Jansky, S.H., A.O. Charkowski, D.S. Douches, G. Gusmini, C. Richael, P.C. Bethke, D.M. Spooner, R.G. Novy, H. de Jong, W.S. de Jong, J.B. Bamberg, A.L. Thompson, B. Bizimungu, D.G. Holm, C.R. Brown, K.G. Haynes, V.R. Sathuvalli, R.E. Veilleux, J.C. Miller Jr., J.M. Bradeen, and J. Jiang. 2016. Reinventing potato as a diploid inbred line-based crop. Crop Science 56: 1412-1411.

Janssen, A.W.B., and J.G.T. Hermsen. 1976. Estimating pollen fertility in Solanum species and haploids. Euphytica 25: 577-586.

Jones, H.A., and H.A. Borthwick. 1938. Influence of photoperiod and other factors on the formation of flower primordia in the potato. American Potato Journal 15: 331-336.

King, J.R. 1955a. Pollen and pollination studies on Irish potatoes. American Potato Journal 32: 7-14.

King, J.R. 1955b. Irish potato pollen storage. American Potato Journal 32: $460-466$.

King, J.R., and T.M. Johnston. 1958. Factors affecting Irish potato pollen germination in an artificial environment. American Potato Journal 35: 689-700.

Knight, T.A. 1812. On raising new and early varieties of the potatoe (Solanum Tuberosum). Transactions of the Horticultural Society of London 1: 57-59.

Kramer, L.J., and J. Bamberg. 2019. Comparing methods of ploidy estimation in potato (Solanum) species. American Journal of Potato Research 96: 419-426. 
Krantz, F. 1924. Potato breeding methods III. A suggested procedure for potato breeding. Minnesota Agricultural Experiment Station Technical Bulletin 25: 3-32.

Krantz, F. 1929. Progress in breeding new varieties of white potatoes. American Potato Journal 6: 227-237.

Krantz, F., and A. Hutchins. 1929. Potato breeding methods. II Selection in inbred lines. Minnesota Agricultural Experiment Station Technical Bulletin. 58: 3-26.

Krantz, F., C. Becker, and Z. Fineman. 1939. Incidence and inheritance of pollen sterility in the potato. Journal of Agricultural Research 58: 593-601.

Lawson, H.M. 1983. True potato seeds as arable weeds. Potato Research 26: $237-246$

Lindhout, P., D. Meijer, T. Schotte, R.C.B. Hutten, R.G.F. Visser, and H.J. van Eck. 2011. Towards $F_{1}$ hybrid seed potato breeding. Potato Research 54: 301-312.

Mascarenhas, J.P. 1975. The biochemistry of angiosperm pollen development. The Botanical Review 41: 259-314.

Mihovilovich, E., R. Sanetomo, K. Hosaka, B. Ordonez, M. Aponte, et al. 2015. Cytoplasmic diversity in potato breeding: Case study from the International Potato Center. Molecular Breeding 35: 137.

Mortenson, L.R., S.J. Peloquin, and R.W. Hougas. 1964. Germination of Solanum pollen on artificial media. American Potato Journal 41: 322-328.

Newman, C., and L. Leonian. 1918. Irish potato breeding. South Carolina Ag Expt Stn. Bulletin No. 195.

Olson, A.R. 1987. Ovule maturity in relation to blossom age of a diploid clone of Solanum tuberosum. Canadian Journal of Botany 65: 706709 .

Ordoñez, B., M. Orrillo and M. Bonierbale. 2017. Manual on potato reproductive and cytological biology. Lima (Peru). International Potato Center (CIP). ISBN 978-92-9060-480-8. 65 p.

Pallais, N., N. Fong, and D. Berrios. 1984. Research on the physiology of potato sexual seed production. Innov. Methods propagating potatoes, Report of the XXVIII Planning Conference, pp. 149-168.

Patterson, C. 1953. A method of obtaining fruits in the potato variety Russet Burbank. American Potato Journal 30: 89-91.

Peloquin, S.J., and R.W. Hougas. 1959. Decapitation and genetic markers as related to haploidy in Solanum tuberosum. European Potato Journal 2: 176-183.

Plaisted, R. 1980. Potato. In Hybridization of crop plants, ed. W.R. Fehr and H.H. Hadley, 483-494. Agronomy Books, Madison WI.

Plantenga, F.D.M., S. Bergonzi, J.A. Abelenda, C.W.B. Bachem, R.G.F. Visser, E. Heuvelink, and L.F.M. Marcelis. 2018. The tuberization signal StSP6A represses flower bud development in potato. Journal of Experimental Botany 70: 937-948.

Plantenga, F.D.M., S. Bergonzi, C.W.B. Bachem, R.G.F. Visser, E. Heuvelink, and L.F.M. Marcelis. 2019. High light accelerates potato flowering independently of the $F T$-like flowering signal StSP3D. Environment and Experiment Botany 160: 35-44.

Powell, W., E. Baird, N. Duncan, and R. Waugh. 1993. Chloroplast DNA variability in old and recently introduced potato cultivar. The Annals of Applied Biology 123: 403-410.

Proudfoot, K. 1965. The effects of flowering and berry formation on tuber yield in Solanum demissum Lindl. European Potato Journal 8: 118-119.

Provan, J., W. Powell, H. Dewar, G. Bryan, G. Machray, et al. 1999. An extreme cytoplasmic bottleneck in the modern European cultivated potato (Solanum tuberosum) is not reflected in decreased levels of nuclear diversity. Proceedings of the Royal Society London Ser. B Biol. Sci. 266: 633-639.

Rees-Leonard, O. 1935. Macrosporogenesis and development of the macrogametophyte of Solanum tuberosum. Botanical Gazette 96: 734-750.
Robbins, W. 1917. The botany of crop plants: A text and reference book. Philadelphia: P. Blackiston's Son and Company.

Ross, H. 1986. Potato breeding - problems and perspectives. Berlin and Hamberg: Verlag Paul Parey.

Salaman, R. 1910. Male sterility in potatoes, a dominant Mendelian character; with remarks on the shape of the pollen in wild and domestic varieties. Botanical Journal of the Linnean Society 39: 301-312.

Salaman, R. 1920. The technique of cross-fertilization in potatoes. Potato Magazine 3: 12-26.

Salaman, R. 1926. Potato Varieties. Cambridge: Cambridge University Press.

Salaman, R., and J.W. Lesley. 1922. Genetic studies in potatoes; sterility. The Journal of Agricultural Science 12: 31-39.

Sanetomo, R., and C. Gebhardt. 2015. Cytoplasmic genome types of European potatoes and their effects on complex agronomic traits. BMC Plant Biology 15: 162.

Sanford, J., and R. Hanneman Jr. 1981. The use of bees for the purpose of inter-mating in potato. American Potato Journal 58: 481-485.

Schark, A.E. 1957. A comparison of microsporogenesis in fertile and sterile potato varieties. Ph.D. Thesis, Iowa State University, $62 \mathrm{pp}$.

Simmonds, N. 1963. Experiments on the germination of potato seeds. II. European Potato Journal 6: 69-76.

Simmonds, N. 1997. A review of potato propagation by means of seed, as distinct from clonal propagation by tubers. Euphytica 40: 191-214.

Smyda-Dajmund, P., J. Śliwka, M. Janiszewska, and E. ZimnochGuzowska. 2020. Cytoplasmic diversity of potato relatives preserved at plant breeding and acclimatization Institute in Poland. Molecular Biology Reports 47: 3929-3935.

Stelly, D.M., and S.J. Peloquin. 1985. Screening for 2n female gametophytes, female fertility, and $2 \mathrm{x} \times 4 \mathrm{x}$ crossability in potatoes (Solanum spp.). American Potato Journal 62: 519-529.

Stevenson, F.J., and R.V. Akeley. 1947. Breeding healthy potatoes. Yearbook of Agriculture: 327-332.

Stevenson, F.J., and C.F. Clark. 1933. Artificial light as an aid in potato breeding. American Potato Journal 10: 103-107.

Stevenson, F.J., and C.F. Clark. 1937. Breeding and genetics in potato improvement. Yearbook of Agriculture USDA: 405-444.

Stout, A., and C.F. Clark. 1924. Sterilities of wild and cultivated potatoes with reference to breeding from seed. Bulletin No. 1195. U.S. Department of Agriculture.

Stow, I. 1926. A cytological study on the pollen sterility in Solanum tuberosum. Proceedings of Imperial Academy 2: 426-430.

Stuart, W. 1914. Disease resistance of potatoes. Vermont Agricultural Experiment Station Bulletin 179: 147-183.

Stuart, W. 1928. The Potato: Its culture, uses, history, and classification. Lippincott, Philadelphia and London: Third. J.B.

Sutton, A. 1898. The potato. Journal of the Royal Agricultural Society of England 9: 581-653.

Thijn, G.A. 1954. Observations on flower induction with potatoes. Euphytica 3: 28-34.

Towill, L.E. 1984. Seed set with potato pollen stored at low temperatures. American Potato Journal 61: 569-575.

Trognitz, B. 1991. Comparison of different pollen viability assays to evaluate pollen fertility of potato dihaploids. Euphytica 56: 143 148.

Upadhya, M., K. Thakur, A. Juneja, and M. Kadian. 1985. Potato true seed production: Flowering, quality, and economics. Innovative methods for propagating potatoes: Report of the XXVIII planning conference, 117-147. Peru: Lima.

US Potato Genebank. 2017. How to make a flower pollen buzzer. https:// www.youtube.com/watch?v=SQddcAiGBhE. Accessed 20 Oct 2020. 
Weatherhead, M.A., B.W.W. Grout, and G.G. Henshaw. 1978. Advantages of storage of potato pollen in liquid nitrogen. Potato Research 21: 331-334.

Werner, H. 1941a. Effect of berry production on varied day length during the life of two triumph potato strains. American Journal of Potato 18: $174-178$.

Werner, H. 1941b. Flower and berry production by potatoes as influenced by two light intensities and two midwinter planting dates. American Potato Journal 18: 349-355.
Williams, E.J. 1954. Seed failure in the potato (Solanum tuberosum L.) varieties Chippewa and Katahdin. Ph.D. thesis, University of Wisconsin-Madison.

Young, W. 1922. Some phases of breeding work and seed production of the Irish potato. South Carolina Agricultural Experiment Station Bulletin 2.

Young, W. 1923. The formation and degeneration of germ cells in the potato. American Journal of Botany 10: 325-335. 